\title{
Character Education Value Content in a Collection of Short Stories Compass 2018 Doa yang Terapung
}

\author{
Prarasto Miftahurrisqi ${ }^{1}$, Suyitno $^{2}$, Sumarwati $^{3}$ \\ 1,2,3Universitas Sebelas Maret, Surakarta, Indonesia \\ Email: prarasto@student.uns.ac.id, yitsuyitno52@gmail.com, sumarwati@staff.uns.ac.id
}

\begin{abstract}
Character education can be instilled in various ways. One of them is through literature. Literature itself is very diverse until now. Among young people, one of the works that have a lot of interest is short stories (short stories), because a short story contains interesting stories to read. In addition, the work also contains a message about positive things. This study aims to describe the value of character education in the collection of short stories Compass 2018 Doa Yang Terapung. Research is included in qualitative research. The method in this study uses descriptive qualitative. The data source in this study is a collection of short stories from Compass 2018 Doa Yang Terapung. Data collection in this study was carried out by reading and understanding short stories and recording data containing the value of character education in the 2018 Compass short story collection Doa Yang Terapung. Data analysis in this study uses the Miles and Huberman flow model, namely data reduction, data presentation, and concluding. The results of this study indicate the values of character education in the 2018 Kompas short story collection Doa Yang Terapung, among others a) the value of religious character education (the value of religious character praying to God, the value of religious character accepting destiny, the value of religious character believing $\mathcal{E}$ surrendering to God's destiny; b) the value of nationalist character education (the value of nationalist character, the spirit of heroism, the value of nationalist character). willing to sacrifice for his family, and c) the value of independent character education (character values of a good work ethic, professional character values, creative character values).
\end{abstract}

Keywords: value of character education; compass short story collection 2018; doa yang terapung

\section{Introduction}

Literary works can be said as a form of human expression, with literary works one can express his thoughts/feelings which are poured into written form, both imaginative and real. Literary works can also be said to be the result of a human initiative that contains a high artistic value. Creating a literary work requires a lot of effort. Many aspects must be considered when creating literary works, for example, aspects of beauty or the benefits of literary works. In addition, a writer/poet will express his ideas based on his daily experiences. Many literary works that reflect the social life of a society are expressed in the form of stories (Nofiyanti, 2014).

Literary works are divided into two forms, namely poetry and prose. Prose consists of several varieties, one of which is short stories (short stories). The role of short stories in recent literary works is to provide a form of novelty or innovation from prose, in addition to novels and essays in the process of describing everyday human life. So, short stories can be said as literary works that describe everyday life because they are played by story characters. In this short story, characters are playing their respective roles to make a story a success. The existence of literary works is expected to make a positive contribution to today's young 
generation, coupled with the increasingly advanced technology that makes the younger generation easier and sometimes lazy.

The rapid change in the reality of life, one of which is marked by advances in technology, science, and art. It is undeniable that changes in behavior, character \& life force also occur in everyday life. The negative impact caused by technological advances is the birth of an instant, pragmatic, hedonistic, and even individualistic perspective and thinking. To deal with these negative things, it takes the ability and willingness of various parties to reaffirm the values of character education. One of the problems the nation is currently experiencing is the fading of the culture of greeting each other, caring for one another, the fading of the culture of respecting each other's performance and helping each other. With this gotong royong character, it is hoped that this can be a solution in alleviating these problems. The need for planting character education starting from the family, school, and community environment. The role of religion is also expected to meet human needs in terms of balancing the character of students (Atika, 2014; Supriyono, et al; 2018; Maulana, 2020; Suryanti \& Widayanti, 2018). To build Indonesia into a superior country, one of them starts from the younger generation. Today's young generation must be prepared through education. In addition to building knowledge (cognitive) and skill (psychomotor) competencies, education is also important for building character. Education is considered the best place to prepare agents of national change who will bring prosperity to society. In addition, through education, we can instill the basic values and character of the nation to the entire younger generation. One type of education that must be given to humans is character education. Character education is very important to be taught to humans because, with character, humans will become noble and become special beings. Education produces habits of life for a person. This can be seen from changes in cultural values that exist in individuals and their communities (Jamrah, 2016; Rokhman, et all; 2014; Munawaroh, 2019; \& Kuning, 2018).

\section{Review of Literatures}

Character education can be done to the younger generation in several ways, one of which is through literary works. Literature has a role in character education, because literature in children's education plays a role in developing language, developing cognitive, affective, psychomotor, personality development, and developing social personality. Besides, literary works also contain a mandate that contains positive character values. Character education in Indonesia has become a non-negotiable need. National education is not only aimed at producing intelligent and skilled humans, but also humans with noble character. Character education not only makes a person have a noble character but also can improve his academic quality. Character education needs to be carried out to face the reality of the development of the 21 st-century world which also has a major influence on changes in the morals and behavior of Indonesian people, especially the younger generation. Character education is carried out to strengthen the competence of youth in the social field. In addition, character education also trains teenagers to be responsible in their social life. Solidarity character education can also be used to prevent social problems in human life by prioritizing the principle of humanity. It is also very important to teach the character of hard work to today's young generation because hard work can train young people who are superior and ready to build their own country through good education competent (Septiadi, et all; 2019; Cheung, 2010; Kanzunnudin, 2012; Sukardi, 2016; Amaliah, ett all; 2018; Hanani, 2016; \& Kusnoto, 2017). 
The cultivation of character values is not only centered on the educational process of the younger generation but also lies in the individuals in educational institutions. One of the educational institutions that can train to instill character education is a school. Between schools, educators, and students are interrelated. They cannot be separated from each other. Educators should be responsible for referring to learning based on religious moral values and Pancasila. Education and reason are two things that cannot be separated because education is only applied to those who have a reason. The example of education that is seen as the most effective is exemplary, namely, the educator provides examples of direct actions/speech, then imitated directly by students so that students do good deeds as well. Exemplary requires unity between educators in various environments, both family, school, and community environments. Therefore, religious education is included in the field of pedagogical education which incorporates religious principles into children's education (Biesta, 2010; Watson, 2019; Cahyaningrum, 2017; \& Ene, 2015).

Character education can be said as all efforts made by educators to shape the character of students. Character education is expected to build superior human resources. Character education must always be instilled in students, besides that character education is very necessary for students to develop their potential. Character education can involve students directly with real problems that are supported by reasoning in their environment. Character education trains students' belief that they seek guidance and want to live a discipline dife to provide a sense of order in their lives. In general, a teacher is expected to be able to contribute to each of his students to live socially and in society (Supranoto, 2015; Koesoema, 2015; Tyas, 2020; Zlatkovic, 2012; Arthur, et all; 2006; Intania \& Sutama, 2020).

Ikromovna, 2021 \& Wening 2012 states that humans and society form a unity that cannot be separated in everyday life. One way for the younger generation to socialize is by using literary works associated with social and cultural learning. Character education must not only be shown by educators in the family, school, and community environment but character education must also be shown by the mass media. One of the most popular mass media today is Kompas. This research will focus on a collection of short stories published by Kompas Book Publishers in 2019 as the first printing with a total of xviii +214 pages. This collection of short stories has character education learning through the mandate inserted by the author both morally, ethically, culturally, and religiously in the storyline following what is in everyday life.

\section{Discussion}

\subsection{The Value of Religious Character Education in a Collection of Short Stories Compass 2018 Doa Yang Terapung}

The value of religious character education is the value of character education that has a relationship between humans and religious teachings and divine morals in everyday life. Researchers found the value of religious character education contained in the Compass Short Story Collection 2018 Doa Yang Terapung. The following quote contains the value of religious character education.

1) "Bacaan doa Bilal Jawad sangat fasih. Sayup dan terang ganti berganti, seolah katakata suci itu telah terbang menjauh meninggalkan kami yang duduk bersila, tetapi lalu kembali lagi ketika lafaznya dikeraskan. Doa yang dirapalnya terbilang panjang dan lengkap, ibaratnya dari A sampai Z. Setengah bergurau, orang kampungku biasa berkata, "Berdoa bersama Bilal Jawad serasa doa setahun diringkas satu hari, semua permintaan ada". (Aroma Doa Bilal Jawad in the Compass, 2019: 4) 
Excerpts from the short story entitled Aroma Doa Bilal Jawad in data (1) This proves the value of religious character education, namely prayer activities. Prayer is one of the activities carried out by humans to offer prayers to God according to their beliefs. Prayer activities can be seen in the quote from the story in data (1), namely Doa yang dirapalnya terbilang panjang dan lengkap, ibaratnya dari A sampai Z. Story quotes in data (1) It describes a story character named Bilal Jawad who in his attitude prays to God for the common good as a form of a religious character.

2) "Terlabir sebagai seorang buta tidaklah begitu buruk. Setidaknya bagiku. Aku masih bisa merasakan hangatnya sinar mentari di permukaan kulitku, juga masih mampu meminta tambah untuk setiap masakan Simbok. Aku tak terlalu menderita. Selama hidungku masih dapat menghirup udara seberapa pun yang kumau, aku masih terhitung bahagia”. (Baruna in the Compass, 2019: 122)

Excerpts from the short story entitled Baruna in data (2) proves the content of the value of religious character education, namely accepting destiny. Destiny is one of the absolute determinations of fate and provisions that come from God to humans. Accepting destiny is seen in the story quoted in data (2), namely "Terlahir sebagai seorang buta tidaklah begitu buruk". The story quoted in data (2) describes the character in Aku's story who in his attitude accepts the condition of blindness and has no remorse for himself as a form of a religious character.

3) "Setelah didera berbagai kegagalan, Marbangun memutuskan untuk berserah kepada Tuban, menjauhkan diri dari godaan duniawi. Dia ingin ikut membangun masyarakat yang bertakwa dan berakhlak mulia". (Ayat Kopi in the Compass, 2019: 184).

Excerpts from the short story entitled "Ayat Kopi" in data (3) proves the content of the value of religious character education, namely piety. Piety is a personal realization or selfawareness with obedience and obedience in carrying out God's commands and staying away from all His prohibitions. Piety can be seen in the story quotes in data (3), namely "Marbangun memutuskan untuk berserah kepada Tuhan". The story quoted in data (3) describes a character named Marbangun who has an attitude like a believer and surrenders to God's destiny as a form of a religious character.

\subsection{The Value of Nationalist Character Education in the 2018 Compass Short Story Collection Doa yang Terapung}

The value of nationalist character education is the value of character education that can reflect an attitude of pride as a nationalist, achievement for the nation, and love for the homeland. Researchers found the value of nationalist character education contained in the 2018 Compass Short Story Collection Doa Yang Terapung. The following are the results of the researcher's analysis of several story quotes in the 2018 Compass Short Story Collection Doa Yang Terapung which contains the value of nationalist character education.

1) "Enam puluh tahun yang lalu ketika bersekolah, dinding ruang kelasnya digantungi gambar para pahlawan. Juga para tokoh bangsa. Tentu saja mereka telah melakukan sesuatu yang luar biasa bagi bangsanya. Mardanu juga tahu dari cerita orang-orang, pamannya sendiri adalah seorang pejuang yang gugur di medan perang kemerdakaan. Orang-orang sering memuji mendiang paman. Cerita tentang sang paman kemudian dikembangkan sendiri oleh Mardanu menjadi bayangan kepahlawanan; seorang pejuang muda dengan bedil bersangkur, ikat kepala pita merah putih, maju dengan 
gagah menyerang musuh, lalu roboh ke tanah dan gugur sambil memeluk bumi pertiwi".

(Lelaki Yang Menderita Bila Dipuji in the Compass, 2019: 148)

Excerpts from the short story entitled "Lelaki Yang Menderita Bila Dipuji" in data (1) proves the content of the value of nationalist character education, namely heroism. Heroism is a matter of traits possessed by a knight or hero such as courage, might, and willingness to sacrifice. Heroism can be seen in the story quotes in data (1), namely "Mardanu juga tahu dari cerita orang-orang, pamannya sendiri adalah seorang pejuang yang gugur di medan perang kemerdakaan". The story quoted in data (1) describes a character named Mardanu who has the attitude of wanting to imitate the spirit of heroism as a form of nationa list character such as the behavior of his uncle who died defending independence.

2) "Pukul rata semua dianggap berhaluan kiri jika menolak menandatangani pernyataan mengutuk pemimpin terguling. Bapak termasuk yang menampik karena merasa berbutang budi sudah diberi kesempatan sekolah tinggi. Jadilah, ia pelarian, diburu sampai ke Vietnam. Kami berdua lahir di tengah sisi kecamuk perang, di Ho Chi Minh City yang masih porak poranda. Ibu lalu membawa Anna kembali ke Leningrad dan aku dititipkan kepada entah siapa, pulang ke Amlapura. Bapak tetap tinggal dan menjadi dokter rumah sakit militer setempat. Setelah itu, semua gelap. Tak ada kabar, Ibu hanya mendengar Bapak tertembak, jasadnya tak terjejak". (Sepasang Matroshka in the Compass, 2019: 156).

Excerpts from the short story entitled "Sepasang Matroshka" in data (2) proves the content of the value of nationalist character education, namely being willing to sacrifice. Selfsacrifice is a devotion or full loyalty by giving something as a sacrifice for a particular interest. The willingness to sacrifice can be seen in the quote from the story in data (2), namely "Bapak termasuk yang menampik karena merasa berhutang budi sudah diberi kesempatan sekolah tinggi". The story quotes in the data (2) describe the characters in the story Bapak who has an attitude of sticking to his stance and is willing to sacrifice as a form of nationalist character both towards his own family and even the country.

\subsection{The Value of Independent Character Education in the 2018 Compass Short Story Collection Doa yang Terapung}

The value of independent character education is the value of character education that has a relationship between attitudes and efforts from within the individual by using all efforts, both work ethic, professional and creative to avoid dependence on others. Researchers found the value of independent character education contained in the short story collection of Kompas 2018 Doa Yang Terapung. The value of independent character education contained in the 2018 Compass Short Stories collection Doa Yang Terapung among others, 1) good work ethic 2) professional, and 3) creative. The following are the results of the researcher's analysis of several story quotes in the 2018 Compass Short Story Collection Doa Yang Terapung which contains the value of independent character education.

1) Good Work Ethic

"Ya, Bu," jawab Purwati lembut. Sejak awal bekerja, ia memang bukan perempuan trengginas. Cenderung lamban, tetapi pekerjaannya rapi. Tidak mudah diubah sekalipun berulang kali disindir, bukan untuk mengoloknya”.

(Opera Sekar Jagad in the Compass, 2019: 62) 
Excerpts from the short story entitled Opera Sekar Jagad in data (1) proves the value of independent character education in the realm of a good work ethic, namely hard work. Hard work at work is a form of work ethic accompanied by a strong will in trying to achieve goals. Hard work at work can be seen in the quote from the story in data (1), namely "Sejak awal bekerja, ia memang bukan perempuan trengginas. Cenderung lamban, tetapi pekerjaannya rapi". The story quoted in data (1) describes a character named Purwati who has a hard work attitude as a form of independent character in the realm of work ethic in carrying out her work of washing clothes in the laundry.

\section{2) Professional}

"Salah satu cara untuk bisa menjiwai saat menggarap batik pesanan, perempuan yang baru menginjak kepala empat itu mengajukan beberapa pertanyaan laiknya penjaga warung makan menanyai pelanggan. Terlebih dahulu, ia bertanya, kain batiknya untuk siapa? Akan dikenakan sendiri? Dalam rangka apa? Acara keluarga, pesta atau dinas? Atau, akan dihadiahkan pada orang lain? Istri? Suami? Teman? Orangtua? Saudara? Sahabat dekat? Atasan? Anak buah?”.

(Pemesan Batik in the Compass, 2019: 21)

Excerpts from the short story entitled Pemesan Batik in data (2) proves the value of independent character education in the professional realm, namely maintaining the trust of others. Maintaining trust is a form of professionalism that is used to build a good relationship at work with fellow human beings. Maintaining the trust of others is seen in the story quotes in the data (2), namely "perempuan yang baru menginjak kepala empat itu mengajukan beberapa pertanyaan laiknya penjaga warung makan menanyai pelanggan". The story quotes in data (2) describe the character of the batik story who has an attitude of maintaining trust as a form of independent character in the professional realm to his customers so that they continue to use their services.

\section{3) Creative}

"Batik buatannya tidak berkutat pada motif dan corak yang sudah dipatenkan sebagai batik Madura, seperti batik Sagarah, Gentongan, Kembang Saladri, Kerraban Sape, Mo'ramo', dan lainnya. Ia membatik dengan menyatukan imajinasi dan jüwa. Menggurat motif dan corak sesuai perasaan pemesan. Semakin kuat jiwa dan perasaan pemesan, semakin hanyut ia dengan cantingnya, semakin halus noktah dan guratan yang dihasilkan, semakin membutuhkan waktu panjang untuk menyelesaikan".

(Pemesan Batik in the Compass, 2019: 21)

Excerpts from the short story entitled Pemesan Batik in the data (3) proves that there is an independent character education value in the creative realm, namely being creative in your work. The creation of one's work is a creative form that uses intuition or imagination to produce a change as a result of that thought. The creation of the work itself can be seen in the quote from the story in data (3), namely "ia membatik dengan menyatukan imajinasi dan jiwa. Menggurat motif dan corak sesuai perasaan pemesan". The story quotes in data (3) describe the character of the batik story who can create the work as a form of independent character in the creative realm in the form of batik patterns and motifs according to customer requests. 


\section{Conclusion}

Based on the results of the analysis of the 2018 Compass Short Stories collection Doa Yang Terapung, it can be concluded that the collection of Short Stories Compass 2018 Doa Yang Terapung contains character education values, including a) religious character education values (religious character values praying to God, religious character values accepting destiny, religious character values believing \& surrendering to God's destiny; b) nationalist character education values (character values nationalist heroic spirit, the value of a nationalist character who is willing to sacrifice for his family; and c) the value of independent character education (character values of a good work ethic, professional character values, creative character values).

\section{References}

Amaliah, Dina. Sariyatun \& Musaddad, Arif. (2018). Values of Piil Pesenggiri: Morality, Religiosity, Solidarity, and Tolerance. International Journal of Multicultural and Multireligious Understanding. Volume 5. Nomor 5. p 179 - 184.

Arthur, James. Crick, Ruth Deakin. Samuel, Elspeth. Wilson, Kenneth; \& McGettrick, Bart. (2006). Character Education: The Formation of Virtues and Dispositions in 16-19 Year Olds with Particular Reference to the Religious and Spiritual. Canterbury Christ Church University.

Atika, Surya. (2014). Pelaksanaan Pendidikan Karakter (Religius, Cinta Tanah Air dan Disiplin) di SLB Al Ihslaah Padang. E-JUPEKhu (Jurnal Ilmiah Pendidikan Khusus). Volume 3. Nomor 3. p $747-755$.

Biesta, G.J.J. (2010). Why “What Works” Still Won’t Work: From EvidenceBased Education to Value-Based Education. Studies in Philosophy and Education, v29(5). p 491-503.

Cahyaningrum, E. S. et al. (2017). Pengembangan Nilai-nilai Karakter Anak Usia Dini melalui Pembiasaan dan Keteladanan. Jurnal Pendidikan Anak. Volume 6. Nomor 2. p 203213.

Cheung, Chau-Kiu \& Lee, Tak-Yan. (2010). Improving Social Competence through Character Education. Journal Evaluation and Program Planning, Elsevier. p 255 - 263.

Ene, Lonel \& Barna, Luliana. (2015). Religious Education and Teachers' Role in Students' Formation towards Social Integration. Procedia - Social Behavioral Sciences 180. p 30 -35 .

Hanani, Doly. (2016). Pendidikan Karakter Anak Menurut Imam Al-Gazali. Jurnal Ilmiah ALJauhari (JIAJ). Volume 1. Nomor 1. p 46 - 53.

Ikromovna, Tolipova Ozoda. (2021). The Socialization of the Younger Generation and Its Place in Society. International Sicentific and Pratical Online Conference on Human Resources: Problems, Solution, Perspectives. p 237-243.

Intania, E. V. \& Sutama. (2020). The Role of Character Education in Learning During the COVID-19 Pandemic. Jurnal Penelitian Ilmu Pendidikan. Volume 13. Nomor 2. p 129 $-136$.

Jamrah, Alfian. (2016). Shaping Golden Generation through Character Education Toward 100 Years Indonesia. Proceeding International Seminar on Education 2016 Faculty of Tarbiyah and Teacher Training. p $41-50$.

Kanzunnudin, Mohammad. (2012). Peran Sastra dalam Pendidikan Karakter. Seminar Nasional Pendidikan dengan tema "Pendidikan untuk Kejayaan Bangsa"di Universitas Sanata Dharma Yogyakarta.

Koesoeme, Doni. (2015). Strategi Pendidikan Karakter Revolusi Mental dalam Lembaga Pendidikan. Yogyakarta: Kanisius.

Kuning, Dewi Sri. (2018). Character Education for Indonesia in Globalization Era. Jurnal 
Elsa. Volume 16. Nomor 1. p 118 - 126.

Kusnoto, Yuver. (2017). Internalisasi Nilai-Nilai Pendidikan Karakter pada Satuan Pendidikan. SOSIAL HORIZON: Jurnal Pendidikan Sosial. Volume 4. Nomor 2. p 247 - 256.

Maulana, Irwan. (2020). Manajemen Pendidikan Karakter Gotong Royong. Jurnal ISEMA (Jurnal Islamic Education Manajemen). Volume 5. Nomor 1. p 127 - 138.

Munawaroh, Azizah. (2019). Keteladanan sebagai Metode Pendidikan Karakter. Jurnal Penelitian Pendidikan Islam. Volume 7. Nomor 2. p 141-156.

Nofiyanti. (2014). Pendidikan Karakter dalam Cerpen "Robohnya Surau Kami" karya A.A Navis. SEMANTIK (STKIP Siliwangi Journals). Volume 3. Nomor 2.

Rokhman, Fathur. Hum, M. Syaifuddin, Ahmad \& Yuliati. (2014). Character Educatioin for Golden Generation 2045 (National Character Building for Indonesia Golden Years). p 1161-1165.

Septiadi, Hidayat Nur. Andayani \& Wardani, Nugraheni Eko. (2019). Planting Base Value of Hardworking Character Education through Ulid Novel. BirLE-Journal (Budapest International Research and Critics in Linguistic and Education. Volume 2. Nomor 3. p $36-44$.

Sukardi, Ismail. (2016). Character Education Based on Religious Values: an Islamic Perspective. Ta'dib Journal of Islamic Education. Volume 21. Nomor 1. p 41 - 58.

Supranoto, H. (2015). Implementasi Pendidikan Karakter Bangsa dalam Pembelajaran SMA. Jurnal Promosi: Jurnal Pendidikan Ekonomi UM Metro. Volume 3, Nomor 1. p 36 49.

Supriyono, Sugeng. Wardani, Nugraheni Eko \& Saddhono, Kundharu. (2018). Nilai Karakter Tanggung Jawab dalam Sajak-Sajak Subagio Sastrowardoyo. RETORIKA: Jurnal Bahasa, Sastra dan Pengajarannya. Volume 11. Nomor 2. p 183 - 193.

Suryanti, Eny Wahyu \& Widayanti, Febi Dwi. (2018). Penguatan Pendidikan Karakter Berbasis Religius. Conference on Innovation and Application of Science and Technology (CIASTECH 2018). p $254-262$.

Tyas, E. Handayani; Sunarto \& Naibaho, Lamhot. (2020). Building Superior Human Resources through Character Education. TEST (Engineering \& Management). p $11864-11873$.

Watson, L. (2019). Educating for Inquisitiveness: A Case Against Exemplarism for Intellectual Character Education. Journal of Moral Education. https://doi.org/10.1080/03057240.2019.1589436

Wening, S. (2012). Pembentukan Karakter Bangsa melalui Pendidikan Nilai. Jurnal Pendidikan Karakter. Volume 2. Nomor 1. p 55 - 66.

Zlatkovic, Blagica \& Misica, Danijela. (2012). Teachers' Education for a More Flexible Apprroach to Character Analysis in Literacy Creations. Procedia - Social and Behavioral Sciences. The 5 th Intercultural Arts Education Conference: Design Learning. p $486-492$. 